\title{
A typological shift in the phonological history of German from the perspective of licensing scales
}

\author{
MARCIN FORTUNA
}

Received 15.01.2018, received in revised form 19.06.2018, accepted 29.06.2018.

\begin{abstract}
The paper argues that the typological shift of German from a syllable language to a word language (Szczepaniak 2007) can be accounted for through reference to a change at the level of the nuclei and their licensing abilities (Cyran 2003, 2010). Old High German used full nuclei in all positions of the word. In the late Old High German period, unstressed vowel reduction took place and entailed a domino effect of further changes. Reduced vowels were granted more licensing potential, and empty nuclei were strengthened too. This parametric shift is assumed to lie at the heart of the whole typological shift. There is no need to state that Old High German "profiled" the syllable, while Modern High German "profiles" the word, since most of the associated phenomena can be explained with more basic mechanisms.
\end{abstract}

\section{Keywords}

syllables, licensing scales, CVCV, German, phonological typology 


\title{
Zmiana typologiczna w fonologicznej historii języka niemieckiego z perspektywy skal licencjonowania
}

\begin{abstract}
Abstrakt
Celem artykułu jest dowiedzenie, że przemiana typologiczna w historii języka niemieckiego $z$ jezzyka sylabowego w język wyrazowy (Szczepaniak 2007) może zostać wyjaśniona za pomoca odniesienia do zmiany na poziomie ośrodków sylabicznych oraz ich zdolności do licencjonowania (Cyran 2003, 2010). Język starowysokoniemiecki używał pełnych ośrodków we wszystkich pozycjach wyrazu. W późniejszym okresie języka starowysokoniemieckiego na sile przybrały procesy redukcji samogłosek, które pociagnęły za sobą dalsze zmiany w systemie fonologicznym. Samogłoski zredukowane oraz ośrodki puste zwiększyły swoje możliwości licencjonujace. Ta zmiana parametryczna jest podstawa całej przesuwki typologicznej. Nie ma więc potrzeby zakładania, że język starowysokoniemiecki „profilował” sylabę, podczas gdy współczesny język niemiecki „profiluje” wyraz, ponieważ większość związanych $z$ tą zmiana zjawisk da się wyjaśnić poprzez odniesienie do bardziej podstawowych mechanizmów.
\end{abstract}

\section{Słowa kluczowe}

sylaby, skale licencjonowania, CVCV, język niemiecki, typologia fonologiczna

\section{Introduction}

Szczepaniak (2007) provides an excellent analysis of the phonological development of German from a typological perspective. She argues that Old High German (henceforth OHG) was a canonical "syllable language" whereas Modern High German (henceforth ModHG) is a prime example of a "word language". Middle High German (MHG) was a transition period.

The aim of this paper is to argue that this shift, albeit indubitably "real", is actually a reflection of a more basic shift in the vocalic system of the language. The explanation will be 
formulated within the Complexity Scales and Licensing (henceforth CSL) framework (Cyran 2003, 2010).

Section 2 will include an introduction to the typology of "syllable" and "word languages", upon which Szczepaniak's (2007) seminal work is based. Section 3 will introduce readers to the model of Complexity Scales and Licensing, developed in Cyran (2003, 2010). Finally, Section 4 will contain a reanalysis of various phonological changes between $\mathrm{OHG}$ and later periods through the prism of CSL.

\section{Syllable languages and word languages}

According to the proponents of the approach to phonological typology distinguishing between "syllable" and "word" languages (Donegan and Stampe 1983, Dauer 1983, Auer 1993, Reina and Szczepaniak 2014), not all units of the Prosodic Hierarchy are treated on a par within a language. Each language chooses one prosodic category and decides to organise its phonology around it. Thus, some languages "profile" the syllable, while others optimise and emphasise the Phonological Word.

The distinction between "syllable" and "word" languages is a new incarnation of the old dichotomy between "syllabletiming" and "stress-timing" (Pike 1953, Abercrombie 1967). Nonetheless, whereas the old theory was based on the phenomenon of rhythm only, the new approach has a much wider scope. It specifies quite clearly what phonological phenomena are characteristic of each type.

Thus, one of the principal features of syllable languages is simple syllable structure. Canonical syllable languages tend to possess either only CV syllables or syllables which fall relatively close to this ideal unmarked shape. Syllable structure is also the same for all word positions, with no visible preferences concerning, for example, the presence of stress. In contrast, word languages archetypally make use of more marked syllabic structures, e.g. closed syllables. They often have large 
consonant clusters, which may violate typical sonority-based generalisations (and which often get repaired through epenthesis in syllable languages). They also may not treat stressed and unstressed syllables equally, with stressed syllables being significantly more "robust" and allowing more variation than the unstressed ones.

There are also significant differences in the behaviour of vocalic systems in both types of language. Syllable languages usually do not exhibit vowel reduction in unstressed positions. They may even contrast vocalic length in unstressed syllables. Such a phenomenon is unlikely to be found in a word language, since word languages place severe limitations on the unstressed vocalism, sometimes limiting it to just one reduced vowel.

Syllable languages are much more likely to use vowel harmony, tone, or geminates. They also often resyllabify consonants across morphosyntactic boundaries. Word languages very rarely display such properties.

How the alleged "profiling" and "optimisation" manifest themselves should naturally follow from the short explanation given above. All of the enumerated regularities found in syllable languages appear to have one common goal: to bring each syllable as close to the CV-shape as possible. On the other hand, the features found in word languages seem to have the emphasis of the Phonological Word as their objective. Each word in such a language has phonological properties which mark its discreteness in the speech chain. It typically has one stressed syllable, the word boundaries are often marked by distinct phonotactic patterns, and they do not get obliterated by resyllabification.

\section{Complexity Scales and Licensing}

Cyran's (2003, 2010) Complexity Scales and Licensing theory is a derivative of Government Phonology, and more precisely of its CVCV implementation. It is an avantgarde model of phonol- 
ogy in that its constituent structure is markedly different from mainstream models. Like other CVCV-related models, it does not grant recognition to traditional units of Prosodic Hierarchy, such as the syllable. The constituent structure is flat, which means that skeletal slots are not dominated by any higherorder prosodic units. The smallest unit manipulated by phonology is a CV-slot. C stands for consonant (onset), $\mathrm{V}$ for vowel (nucleus). It is not possible to refer to a $\mathrm{C}$ or $\mathrm{V}$ on its own, since they form an indivisible prosodic unit. Nevertheless, some CV slots may remain unassociated with phonetic substance (melody). In such a case they remain unpronounced. Figure 1 illustrates a CVCV representation of English "guarantee".

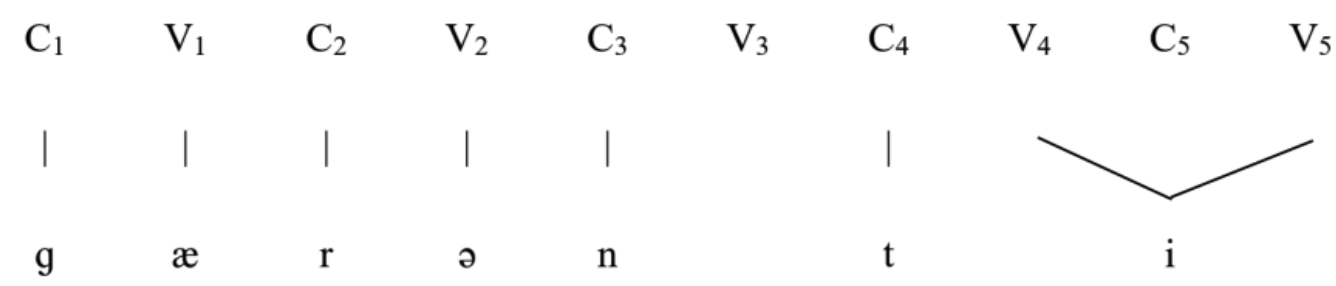

Figure 1

Guarantee in $\mathrm{CVCV}$

As we can see, the consonant cluster /nt/ extends over two $\mathrm{CV}$-slots. There is a V-position in between, which happens to not be associated with melody (hence a cluster on the surface). Likewise, the long vowel / $\mathrm{i}$ / contains an empty onset position.

Even though there are no syllables, there is syllable structure. This means that CVCV can still express a contrast e.g. between a closed and an open syllable, or explain syllablebased phonotactics restrictions. All of the observations conventionally accounted for by means of syllabic arborescence are attributed here to the workings of lateral forces. Lateral forces are defined as relations between prosodic positions in 
a string. The inventory of recognized lateral forces is a matter of dispute. Within the limits of this paper, we will review only the lateral forces found in the CSL model.

In the absence of branching constituents (onsets, rhymes), the existence of all consonant clusters follows from the socalled interonset relations contracted between $\mathrm{C}$-positions across an intervening $\mathrm{V}$-slot. It is typically a matter of the sonority profiles of participating consonants whether the sequence at hand is parsed as a branching onset or a coda-onset cluster. The stronger, i.e. the less sonorous member of the cluster, becomes the head of a relation called Interonset Government. If the consonant on the left is stronger, the contracted relation is referred to as Rightward InterOnset Government (RIO) and a branching onset arises. In the opposite case, consonants form a coda-onset cluster by establishing a Leftward InterOnset Government (LIO) relationship.

One more later force, licensing, plays an important role in CSL. Licensing is a property of nuclei and is a condition on the existence of all consonantal structures. Every single consonant needs to be licensed by the following nucleus. For instance, in the word cat /'kæt/ the nucleus /æ/ licenses the preceding $/ \mathrm{k} /$, whereras / $\mathrm{t} /$ is licensed by the following empty nucleus. Please keep in mind that consonant-final words need to be assumed to end in empty nuclei, if the CV-slot is the smallest prosodic unit. Licensing is also a condition sine qua non for clusters. For LIO or RIO to be contracted, the potential governor needs to be licensed to govern by the following nucleus. This relation is known as Government-Licensing. Figure 2 contains a graphical illustration for all of the hitherto discussed formal mechanisms. 
a) simple licensing

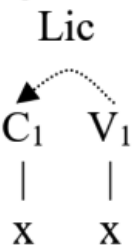

b) Leftward IO

LIO Gov-Lic

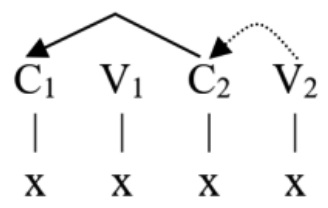

c) Rightward IO

Gov-Lic

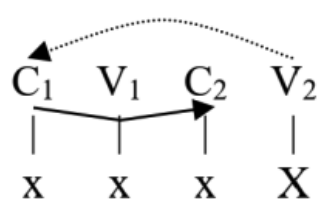

RIO

Figure 2

Interonset relations in Cyran (2010)

Not all of the structures in (2) are equally easy to licence. Note that the single consonant $(2 \mathrm{a})$ is the most common situation, in which a nucleus licences a single onset. In (2b) the nucleus licenses two consonants, which is a more difficult task. Finally, in (2c) the nucleus is responsible for two consonants as well, but its licensee is more distant from it. This relation is not only a theoretical construct, since it mirrors the scale of markedness put forward in Kaye and Lowenstamm (1981) as a cross-linguistically prevalent universal. Single onsets are indeed the least marked structures, with coda-onset clusters being more marked and branching onsets as the last step of the scale.

According to CSL, this set of implications belongs to the core of phonological UG and is regulated parametrically in various languages. Should a language possess coda-onset clusters, it necessarily also has singleton onsets. If it has branching onsets, it must also display both singleton onsets and coda-onset sequences. Figure 3 displays the relations.

\begin{tabular}{|c|c|c|c|c|c|}
\hline & Structure & Example & example & & \\
\hline I & $C \underline{a}$ & baby & Desano & 7 & \\
\hline II & $R T \underline{a}$ & winter & Japanese & & \\
\hline III & $T R \underline{a}$ & trap & English & & $\downarrow$ \\
\hline
\end{tabular}

Figure 3

Licensing strength of nuclei in Cyran (2010: 93) 
$\mathrm{C}$ in Figures 3 and 4 refers to any consonant, RT is a sequence of any sonorant followed by any obstruent (i.e. a typical codaonset cluster), whereas TR is its reverse, i.e. a canonical branching onset. The following figures use the same conventions.

The last important concept in CSL is the strength of the nuclei which carry out the job of licensing. That is, a full vowel is always inherently stronger, and can license more (or at least not less) than a reduced vowel. Analogously, an empty nucleus is even weaker than a reduced vowel, so it will never license more than a reduced, or a full, vowel. Figure 4 contains a full demonstration of the implicational relationships lying at the heart of the CSL model.

\begin{tabular}{|c|c|c|c|c|c|}
\hline & [a] & & [ə] & & [Ø] \\
\hline \multirow[t]{2}{*}{ I $\mathrm{C}_{-}$} & $\mathrm{Ca}$ & $\subset$ & $\mathrm{Ca}$ & $\subset$ & CØ \\
\hline & $\cap$ & & $\cap$ & & $\cap$ \\
\hline \multirow[t]{2}{*}{ II $\mathrm{RT}_{-}$} & $\mathrm{RTa}$ & $\subset$ & RTə & $\subset$ & RTØ \\
\hline & $\cap$ & & $\cap$ & & $\cap$ \\
\hline III $\mathrm{TR}$ & TRa & $\subset$ & TRə & $\subset$ & TRØ \\
\hline
\end{tabular}

Figure 4

The full net of syllable structure relations in CSL

It does not take much to notice that the theory of CSL is quite a comprehensive proposal, since it aspires to account for virtually all aspects of syllabic organisation. It is also fully falsifiable. In the remainder of the paper we will see that it provides enough formalism to explain the typological shift which apparently took place in German. 


\section{Phonological-typological shift in the history of German}

Our analysis of the shift will consist in juxtaposing the OHG phonological system and the developments which it underwent in the subsequent periods. We will principally concentrate on the changes in the nucleus inventory and the distribution of nuclei. Then we will attempt to relate these changes to other phonological developments and to show that they are often interconnected.

\subsection{The properties of nuclei in OHG}

The vocalism of OHG was that of a typical syllable language. OHG contrasted long and short vowels in both stressed and unstressed positions. Most probably, there was no vowel reduction, at least until the late OHG period.

The inventory of vowels in stressed positions contained five short vowels /a, ë, i, o, u/, five long vowels / $\bar{a}, \bar{e}, \overline{1}, \bar{o}, \bar{u} /$, and six diphthongs /ei, ou, io, iu, ie, uo/. In unstressed positions the inventory was not much smaller. There was some dialectal variation, but except for the fact that the use of diphthongs in unstressed positions was very rare, most of the long and short monophthongs could occur in unstressed positions too.

In CSL terms, OHG made use of only two levels of licensors: full nuclei and empty nuclei (at the end of word). However, when we take a look at the licensing skills of the nuclei, we would expect to see mainly singleton consonants in a syllable language. From the qualitative point of view, this is clearly not the case. Simmler (1981) prepared an exhaustive list of the consonant clusters found in various positions of the word in Otfrid of Weissenburg's Evangelienbuch. It turned out that OHG had both two-member clusters and three-member clusters in all positions of the word (such as nst, rpf, rts etc.).

At the beginning of the word, the clusters mostly consist of two members, and typically do not transcend beyond what we traditionally call "branching onsets". As a possible third mem- 
ber, we may find /s / at the left edge. Word-internally, the system displays a wide variety of two-member and three-member clusters. There are even two four-member clusters attested (rsgt, nsgt). The right edge of the word also features two- and three-member groups, but apparently no clusters ending in a sonorant (the so-called word-final branching onsets).

On this basis, we could conclude that OHG principally had word-language phonotactics, but a closer analysis makes the whole picture quite murky. Some of the clusters included by Simmler (1981) contain a morpheme boundary, which means that they may contain a laterally potent empty nucleus creating its own licensing domain (this is true of both of the attested word-internal four-member clusters). What is more, many of these big clusters contain sibilants, which are the enfant terrible of phonotactics and often form consonant groups which do not fit the remainder of the phonological system at hand, and thus could be exempt from generalisations. Finally, many of them are in fact contour segments (esp. pf, ts) and should not be treated as clusters at all.

Another factor which influences our interpretation of the OHG consonantism is token frequency of the "big clusters". Frey (1988) offers a statistical evaluation of the frequency of all of the syllabic configurations. It appears that word-internal clusters made of three or four clusters have an extremely low token frequency. Less than $1.4 \%$ of the words in the tested corpus possess a word-internal cluster with more than two members (there is no data about the morphological structure of these clusters; it is possible that some of the examples could be dismissed on this basis too). Hence, clusters bigger than two consonants are a very marked situation in OHG, if unambiguous examples can be identified at all.

There are some further phenomena which give us hints concerning the licensing potential of OHG nuclei. Very many clusters display epenthetic vowels on some occasions. The epenthesis seems to be independent of the position of the cluster within the word. Thus, a vowel may be inserted word- 
initially (chraft > charaft 'strength', swarz > sowarz 'black'), word-internally (farwa > farawa 'color', malha > malaha 'bag'), and word-finally (swert > sweret 'sword', kisiht > kisihit 'vision'). Epenthesis also often took place at a morpheme boundary after concatenation (spil 'play, music' + hüs 'house' > spilihūs 'theater'). Syncope, on the other hand, was very rare in $\mathrm{OHG}$, and when it took place, then it was only to create geminates. The CSL interpretation of these facts is that all OHG licensors have a strong preference for singleton onsets. Consonant clusters, even though not entirely non-existent, are not very well embedded in the system.

The licensing potential of the OHG can thus be generalised in the following way:

a) Full nuclei can license all three levels of syllabic complexity (singleton onsets/coda-onset clusters/branching onsets), however, the system has a strong preference for singleton onsets and enforces such structures on many occasions.

b) Empty nuclei can license two levels of syllabic complexity (singleton onsets and coda-onset clusters), but they feature a similar bias towards simple onsets as the most unmarked situation.

Note, however, that employing empty nuclei as licensors was dispreferred, when better options were available. In postlexical contexts it was possible to readjust the syllable structure in a way which would maximize the role of the full nucleus. Consider for example, gemination of a word-final consonant before a word beginning with a vowel, e.g. kan inan > kann inan 'can him' (Braune 2004: 96). 


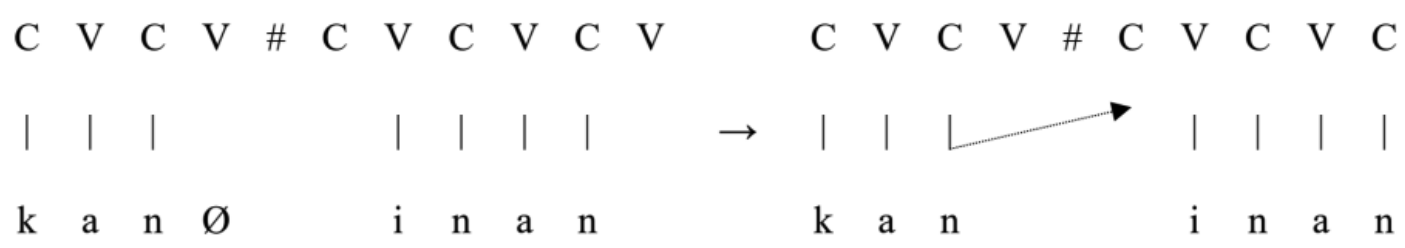

Figure 5

Postlexical gemination in $\mathrm{OHG}$

At the initial stage, a single consonant was licensed by an empty nucleus. Since an empty C-position followed by a better licensor became available after concatenation, melody from the word-final C spread onto it, forming a LIO domain licensed by the initial vowel of inan. Apparently, a more complex structure with a full vowel in the licensor role was preferred over a single consonant licensed by an empty nucleus.

OHG also had some other processes characteristic of syllable languages. Full vocalism in all positions often lays foundations for the existence of vowel harmony. OHG indeed harmonised some of its vowels in the phenomenon of i-umlaut, which was still productive back then and came to be visible in MHG after phonemicization (OHG mahtìg > MHG mähtec 'mighty'). Also epenthetic vowels tended to adapt to the quality of the preceding or following stem vowel (cf. the examples quoted above: chraft > charaft 'strength' vs. swert > sweret 'sword').

All of these facts contribute to the classification of Old High German as a syllable language in terms of the theory of prosodic profiling. In terms of CSL, the same combination of factors could be described by the strong pressure of the system to emphasise full nuclei. The most preferred licensing relation was that which existed between a nucleus and a singleton onset. Other syllabic configurations were also present, but the system had several techniques of eliminating them and enforcing the favoured CV-structure. 


\subsection{The typological shift in late OHG and MHG}

The end of the OHG period was marked by a very significant change at the level of phonological representation. Namely, vowel reduction in unstressed syllables took place. German started losing the hitherto prevalent opposition between long and short nuclei in unaccented positions, replacing all of the old unstressed vocalism by reduced nuclei.

Following the assumptions of CSL, we need to assume that the shift was a parametric change at the level of I-language. When vowel reduction got phonologized, the inventory of licensors was enriched to accommodate the third type of licensor: the reduced vowel. At the same time, i-umlaut vowels lost their conditioning environment and became phonologized too. The inventory of stressed nuclei increased, while the set of unstressed nuclei was decreased.

This change was the step which provided the conditions for the subsequent remodelling of the whole phonological system of German. A prominent modification took place at the foot level, since emphasising the difference between stressed and unstressed nuclei caused the trochee to become the dominant foot type in MHG. Every phonological word acquired a strong tendency to accommodate exactly one foot (Szczepaniak 2007: 149).

In what way did the vowel reduction influence the licensing relations? Note that virtually all full unstressed nuclei (except the ones in compounds) were replaced by reduced vowels. Essentially, the new licensors inherited the consonantal structures of their historical predecessors.

At the same time, however, vowel reduction proceeded further. Some of the reductions ended in vowel loss. As a consequence, increasingly bigger consonantal structures arose, and they needed to be licensed by increasingly weaker licensors. Numerous MHG syncopes and apocopes are the primary symptom of a change at the level of licensors and their respective strengths. 
Let us take a look at the development of several medial unstressed vowels from OHG to MHG (data collected from Szczepaniak 2007, Paul 1998, Löhken 1997: 229).

(1) OHG zunga > MHG zung[ə] 'tongue, nom. sg.'

OHG korōti > MHG kor[ə]t[ə] 'recognize, 3p.sg.past.subj.'

OHG salbōta > MHG salb[a]t[ə] 'anoint, 3p.sg.past'

OHG kelbirum > MHG kelb[ə]r[ə]n 'calves, dat.pl.'

OHG zungōno > MHG zung[ə]n[ə] 'tongue, gen.pl.'

These examples, at least at the initial stage of the reduction process, did not involve any change in the licensing relations. We can only see that the full nuclei (long and short ones) were supplanted by $/ \partial /$, which continued to license the same consonantal structures.

Over the course of time, however, further reductions took place. The examples in (2) demonstrate how some of wordinternal schwas were dropped and created new consonant clusters:

(2) OHG gimeinida > MHG gemeinde 'community'

MHG kelb[ə]r[ə] $n>$ kelb[ə] $r n$ 'calves, dat. pl.'

MHG ner[ə]n $>$ nern 'heal, inf.'

MHG nim[a]t > nimt 'take, 3p. sg. pres.'

MHG hilffə]t $>$ hilft 'help, 3p. sg. pres.'

MHG gib[ə]t > gibt 'give, 3p. sg. pres.'

OHG miluh > MHG milch 'milk'

OHG magad > MHG maget > magt 'maid'

These stress-driven syncopations led to quite a wide-ranging role shift in the system of licensors. For instance, in OHG gimeinida 'community' the full vowel /i/ was responsible for just one preceding consonant $/ \mathrm{n} /$. After it was syncopated (probably with the intermediate stage of reduction to schwa), the $\mathrm{V}$-slot became empty. In order for the position to remain unpronounced, the next vocalic slot (which in OHG hosted /a/, but just /ə/ in MHG) needed to take over the job of licens- 
ing two preceding consonants. Let us analyse the change in the representation in Figure 6.

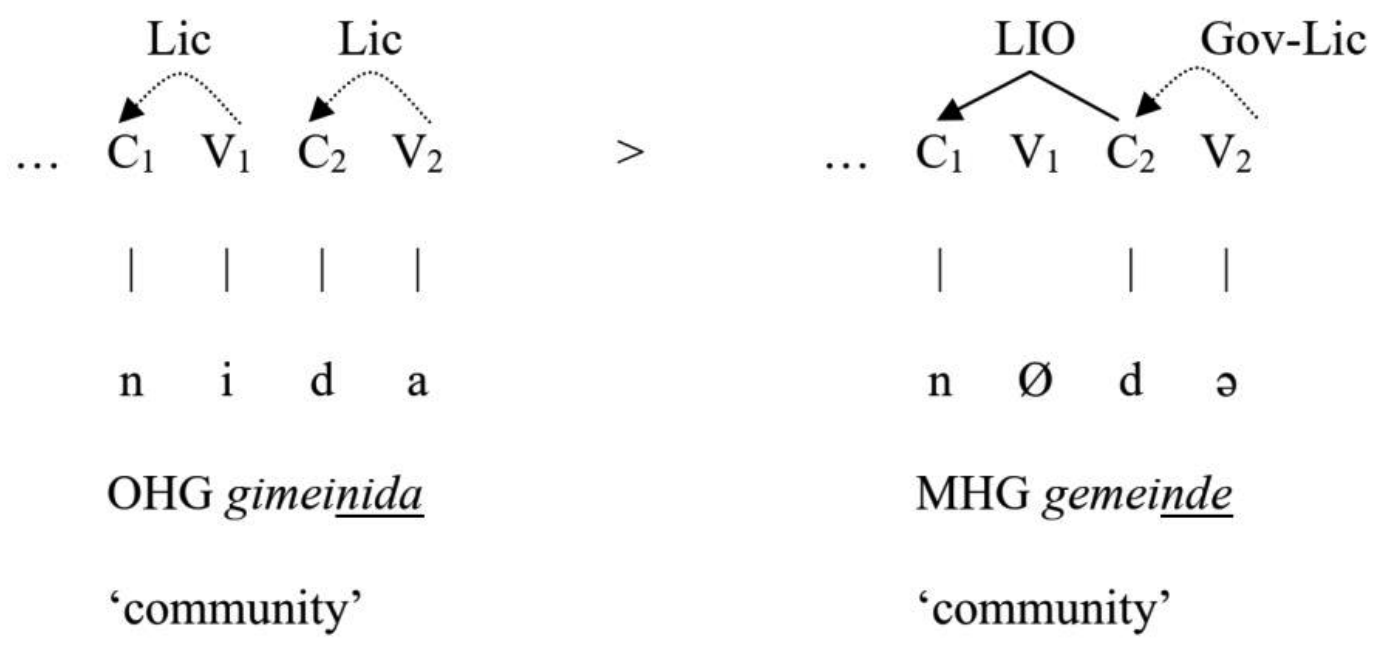

\section{Figure 6}

Licensing responsibility shift from OHG to MHG

The remaining examples from (2) point towards a significant rise of the role of empty nuclei in the system. Final empty nuclei, which licensed only single consonants in (2) before syncope, became burdened with the duty of licensing whole clusters. The battery of syncopations remarkably raised the ratio of word-final consonant clusters in the language.

Beside word-internal schwas, numerous word-final ones got left out too. Many words ending in a vowel became consonantfinal. This was another factor leading to the boosting of the role of final empty nuclei. Consider the following data:

(3) MHG zung[ə]n[ə] > zung[ə]n 'tongue, gen. pl.'

MHG eng[ə]l[ə] > eng[ə]l 'angel, nom. sg.'

MHG vruhtbær[ə] > vruhtbær 'fertile'

MHG spæte > spæt 'late'

MHG lære > lær 'empty' 
Not only were the final empty nuclei granted more licensing duties, but also their prevalence in the lexicon significantly rose.

Note that the syncope and apocope phenomena were independent of the morphological structure of the word - all unstressed vowels could be lost, regardless of whether they belonged to the stem, to a derivational affix or to an inflectional affix. The resulting clusters are also not always canonical coda clusters, since syncope can even generate obstruent sequences, e.g. magt.

All other phonological development which took place in the Middle High German period can be derived from the change at the nuclear level. For instance, MHG lost vowel harmony i-umlaut became morphologised, umlauted vowels were phonemicised. This fact can be directly accounted for by the reduction of the conditioning environment (i.e. all /i/s) to schwa. If unstressed nuclei undergo reduction, it follows that they can no longer express the same range of contrasts which they could before. Consequently, the full nuclei take over the role of lexical contrast bearers. Even though /i/ was no longer distinguishable from other unstressed nuclei, the contrasts which it was responsible for were transferred to the stressed vowel.

Another process which started manifesting itself in the Middle High German period was final devoicing. Devoicing is traditionally perceived in the German linguistic tradition as final fortition (Auslautsverhärtung), rather than weakening. Nowadays, this perspective is still embraced by many linguists (see e.g. Iverson and Salmons 2007, but also Harris 2009 for the opposing view). Iverson and Salmons (2007) postulate that the German final devoicing is best analysed as [spread] feature addition. However, the addition of a feature, or fortition in general, is not a process which could be expected from a weak position, like the word-final one, hence the account seems 
paradoxical. ${ }^{1}$ When we assume that the word-final empty nuclei were strengthened in the transition from OHG to MHG, we may as well link to it the development of Auslautsverhärtung. Final empty nuclei were granted more licensing potential and they needed a way to express it. In consequence, German acquired a process of feature addition in the word-final position.

To sum up the Middle High German period from the viewpoint of CSL, first of all it needs to be stated that it was characterized by the introduction of a new type of licensor: reduced vowels. This was the fundamental change, which, although it may have originated in phonetics, essentially involved a parameter resetting. It was the first and most crucial step of the typological shift. The system was also plagued by frequent deletions of unstressed vowels. As a result, the licensing skills of the nuclei which stayed in the system (reduced and empty nuclei) underwent a significant upgrade.

\subsection{Between MHG and ModHG}

In the early ModHG period, the phonological system of German manifested the features of a typical word language even more explicitly than before. For instance, the stressed nuclei gained more prominence after the process of Open Syllable Lengthening was completed (Szulc 1987: 124, Schmidt 1993: 237). There were only a few developments which are relevant from the point of view of licensing relations in the language.

For instance, many words ending in a single consonant acquired an additional coronal at the right edge (Szczepaniak 2007: 250-51):

(4) MHG ieman > eModHG jemand 'somebody'

MHG saf $>$ eModHG saft 'juice'

MHG obez > eModHG obest/obst 'fruit'

MHG letz > eModHG letzt 'last'

${ }^{1}$ Note that there Iverson and Salmons do not conflate all cases of wordfinal devoicing as fortition - only the ones for which some evidence for feature addition can be adduced. 
In Szczepaniak's terms, the reason behind the process was highlighting the word boundary. In CVCV, the right-edge epenthesis may be attributed to the same factor which was responsible for the emergence of final devoicing. The rise in the licensing potential of final empty nuclei (FENs) led to further modification of the right edge of some words. Their FENs became so strong and potent, that the possibility to license a LIO became an unmarked option. In some cases, the boosted potential of the empty nuclei had to remain unexpressed, or it only caused final fortition. However, sometimes it also led to a right-edge epenthesis.

The strength of FENs may be also one of the reasons why no resyllabification across word and morpheme boundaries takes place in Modern High German (unlike in Old High German). Consider, for example, morphologically complex words like üb+lich ['y:p.lıç] 'usual' or Rad+achse ['ка:t.,Pakslə] 'axle', which could potentially form single domains, pronounced as *['y:.bliç] and *['Ra:, dakslə] respectively. However, the FENs at the right edge of each base are sufficiently independent to prevent such a process from taking place.

\section{Conclusion}

Unlike the proponents of the syllable vs. word language dichotomy, we assume that the vowel reduction in late Old High German was not a result of a typological shift in the phonology of the language. It was rather the only shift in the I-language terms, and the remaining changes followed from it.

This analysis is different from the traditional ones, in that it is based upon completely different theoretical assumptions. It rejects the idea espoused literally in the prosodic profiling literature, according to which one prosodic category is selected by the system and the whole phonology of the language is centered upon it. There are independent reasons to assume that the syllable is not the primary category of human language (Scheer 2004), and that the Prosodic Hierarchy is only a dia- 
critic, the aim of which is to represent morphosyntactic information in phonology (Scheer 2012). Having embraced the achievements of the CVCV theory, it is useful to attempt to reformulate some old generalisations in a new guise, testing at the same time CVCV on the ability to express them with the same explanatory power. It is hoped that this paper shows that CVCV, in Cyran's CSL implementation, is not at a loss when confronted with such topics as phonological typology or comprehensive diachronic reorganisations of the phonological system.

\section{References}

Abercrombie, David (1967). Elements of General Phonetics. Edinburgh: Edinburgh University Press.

Auer, Peter (1993). "Is a rhythm-based typology possible? A study of the role of prosody in phonological typology". KontRI Working Paper 21. Universität Konstanz.

Auer, Peter (2014). "Preface". In: Javier Caro Reina, Renata Szczepaniak (eds.). Syllable and Word Languages. Berlin - Boston: Mouton de Gruyter, 1-7.

Cyran, Eugeniusz (2003). Complexity Scales and Licensing Strength in Phonology. Lublin: Wydawnictwo KUL.

Cyran, Eugeniusz (2010). Complexity Scales and Licensing in Phonology. Berlin - New York: Mouton de Gruyter.

Dauer, Rebecca M. (1983). "Stress-timing and syllable-timing reanalyzed”. Journal of Phonetics 11: 51-62.

Donegan, Patricia J., David Stampe (1983). "Rhythm and holistic organization of language structure". In: John F. Richardson, Mitchell Marks, Amy Chukerman (eds.). Papers from the Parasession on the Interplay of Phonology, Morphology and Syntax, Chicago, 22-23 April 1983. Chicago: Chicago Linguistic Society, 337353.

Frey, Evelyn (1988). Wortteilung und Silbenstruktur im Althochdeutschen. Mit einem Anhang zur mittelhochdeutschen „Speculum ecclesiae“-Handschrift. München: Copy \& Druck. 
Harris, John (2009). "Why final devoicing is weakening". In: Kuniya Nasukawa, Philip Backley (eds.). Strength Relations in Phonology. Berlin - New York: Mouton de Gruyter, 9-46.

Iverson, Gregory K., Joseph Salmons (2007). "Domains and directionality in the evolution of German final fortition". Phonology 24: 121-145.

Jaskuła, Krzysztof (2014). Levels of Interpretation in Sound Systems. Lublin: Wydawnictwo KUL.

Kaye, Jonathan, Jean Lowenstamm, Jean-Roger Vergnaud (1990). "Constituent Structure and Government in Phonology". Phonology 7: 193-231.

Löhken, Sylvia C. (1997). Deutsche Wortprosodie. Abschwächungsund Tilgungsvorgänge. Tübingen: Studien zur deutschen Grammatik.

Lowenstamm, Jean (1996). "CV as the only syllable type". In: Jacques Durand, Bernard Laks (eds.). Current Trends in Phonology. Models and Methods. Salford, Manchester: European Studies Research Institute, Universityof Salford, 419-441.

Paul, Hermann (1998). Mittelhochdeutsche Grammatik. Überarbeitet von Peter Wiehl und Siegfried Grosse. Tübingen: Sammlung kurzer Grammatiken grammatischer Dialekte.

Pike, Kenneth L. (1953). The Intonation of American English. Ann Arbor: University of Michigan Publications. Linguistics 1.

Reina, Javier Caro, Renata Szczepaniak (eds.) (2014). Syllable and Word Languages. Berlin - Boston: Mouton de Gruyter.

Scheer, Tobias (2004). A Lateral Theory of Phonology: What Is CVCV and Why Should It Be? Berlin - New York: Mouton de Gruyter.

Scheer, Tobias (2012). Direct Interface and One-Channel Translation. Berlin - New York: Mouton de Gruyter.

Schmidt, Wilhelm (1993). Geschichte der deutschen Sprache: Ein Lehrbuch für das germanistische Studium. Stuttgart: Hirzel.

Simmler, Franz (1981). Graphematisch-phonematische Studien zum alhochdeutschen Konsonantismus. Insbesondere zur zweiten Lautverschiebung. Heidelberg: Amsterdamer Publikationen zur Sprache und Literatur.

Szczepaniak, Renata (2007). Der phonologisch-typologische Wandel des Deutschen von einer Silbensprache zu einer Wortsprache. Berlin - New York: Mouton de Gruyter. 
Szigetvári, Péter (1999). VC Phonology: A Theory of Consonant Lenition and Phonotactics. Doctoral dissertation. Eötvös Loránd University.

Szulc, Aleksander (1987). Historische Phonologie des Deutschen. Tübingen: Sprachstrukturen. Reihe A: Historische Sprachstrukturen 6.

Valentin, Paul (1978). "The simplification of the unstressed vowel systems in Old High German". In: Jacek Fisiak (ed.). Recent Developments in Historical Phonology. Den Haag: Mouton de Gruyter, 373-390.

Marcin Fortuna

ORCID iD: 0000-0001-5394-8127

Instytut Anglistyki i Amerykanistyki

Uniwersytet Gdański

ul. Wita Stwosza 51

80-308 Gdańsk

Poland

marcin.fortuna@ug.edu.pl 